\title{
MACROPHAGES AND PIGMENT CELLS IN THE LIVER OF PELOPHYLAX RIDIBUNDUS (ANURA)
}

\author{
N. M. Akulenko \\ Schmalhausen Institute of Zoology of NAS of Ukraine, \\ vul. B. Khmelnytskogo, 15, Kyiv, 01030 Ukraine \\ E-mail: akulenkonm2018@gmail.com
}

Macrophages and Pigment Cells in the Liver of Pelophylax ridibundus (Anura). Akulenko, N. M. The morphological features of pigment-containing cells and phagocytic cells were observed on the smears of the liver of the lake frogs. Based on an analysis of more than 1500 cells, it was concluded that cells that have pigment granules in the cytoplasm do not have phagocytic inclusions. On the other hand, phagocytic cells can have pigment inclusions only in the composition of phagocytic vacuoles. Thus, in this organ pigment cells and macrophages are different lines of cell differentiation. For two types of cells, the morphological features characterizing young, functionally active and aging cells are described.

Key words: frog, liver, pigment cells, macrophages.

\section{Introduction}

The presence of pigment-containing cells in internal organs is a characteristic feature of poikilothermic vertebrates. Most researchers consider that pigment-containing cells of the anamnia liver, spleen and kidney are a homogeneous population of macrophages capable of simultaneously both phagocytosis and the synthesis of pigments. To denote them, the term "melanomacrophages" is commonly used (Agius, 1980; Dang et al., 2019). Moreover, the data obtained from the study of melanomacrophages of fish often spread to amphibians "by default" and all visceral pigment cells are considered phagocytic (Sichel et al., 2002; Steinel, Bolnick; 2017; Gutierre et al., 2018). But in many studies, data are presented that indicate the heterogeneity of pigmentcontaining cells in the internal organs of poikilothermic vertebrates (Ribeiro et al., 2011; Diaz-Satizabal, Magor, 2015; Carrola et al., 2019 etc.). Even researchers, who basically consider the pigment cells of all amphibians as melanomacrophages, note their heterogeneity (Corsaro, 2000). Moreover, the same authors describe pigment cells with spines "similar to dendritic cells" (Barni et al., 1999) in the liver of the newt.

Meanwhile, without solving the issue of the nature of pigment-containing cells in the hematopoietic organs of specific anamnia groups, one cannot satisfactorily solve the question of their functional features.

The functions of pigment-containing cells of internal organs have not been fully studied, but they are rather important. It can be considered proven that the pigment reserves of internal organs are used in neutralizing the oxidation products arising during the neutralization of biologically foreign material (Arciuli et al., 2012). 
There is also evidence that melanin stocks are used by hepatocytes of the liver in the performance of their basic functions (de Gregorio et al., 2016). Evidence of the involvement of amphibian liver pigments in organ repair after necrosis of hepatocytes is obtained, which allows to avoid fibrous degeneration of liver tissues (Akulenko, 2016). Proceeding from many empirical data, a number of authors suggest using the determination of the sizes of melanomacrophagal centers and melanin stocks in internal organs as indicators of the physiological state of the animal (Passantino et al., 2014; De Souza et al., 2014; Borucinska et al., 2017; Steinel, Bolnick, 2017). In particular, these indicators can be used to indicate anthropogenic pollution (Akulenko, 2015; Pérez-Iglesias et al., 2016; de Gregorio et al., 2016; Barros et al., 2017). Therefore, the origin and peculiarities of the functioning of pigment-containing cells in various groups of poikilothermic vertebrates are a pressing subject of study.

\section{Material and methods}

The object used 35 mature male frogs (Pelophylax ridibundus) $(8-10 \mathrm{~cm}$ long body weight, weight $45-$ $50 \mathrm{~g}$ ), which were caught in the vicinity of the city of Kyiv. Animals were euthanized with ether anesthesia. For histological examination, liver fragments were selected and liver smears were made. For this purpose, the cut off side of the sample of the liver was quickly carried out over the slide, so that the cells lay down in a thin layer. Unlike the traditional method of making prints, the technique of smears makes it possible to clearly see the morphological features of single cells. Macrophages and pigment cells of tailless amphibians are weakly attached to the connective tissue carcass of the liver and are found on smears in a multitude. The smears were fixed with methanol and stained by Pappenheim. This method allows to recognize blood cells and their predecessors, monocytes, macrophages and even different types of inclusions in macrophages.

On the liver smears for each animal, 50 cells with pattern of macrophages or pigment cells were described. For each cell, the following parameters were fixed: the cell size (in conventional units), the shape and structure of the nucleus, the presence of vacuoles and inclusions, the nature of the inclusions. The pigment content was assessed visually in points. Using the ocular mesh, an increase of 200 determined the large and small diameter of each counted cell. The area of the cell (pigment cell or macrophage) was calculated in conventional units, as a product of a large and a small radius. The standard error and the reliability of the differences were determined using the Student's test.

\section{Results}

On the Rana ridibunda liver prints, individual pigment-containing cells are clearly visible (fig. 1). Basically, these are large cells, with a diameter of about $20 \mu \mathrm{m}$. The nuclearcytoplasmic ratio is low, which is characteristic of mature, functionally active cells.

Pigment is present in the cytoplasm as dark brown granules distributed evenly in the cytoplasm. In addition, vacuoles filled with a pigment in the form of fine grains are often seen. In the first case, we see granules of melanin, and in the second - vacuoles with hemosiderin (Henninger, Beresford, 1990; Akulenko, 1998).

The amount of pigment in cells was estimated visually in points (Heyhoe, Quaglino, 1983). The average pigment content for all the pigment-containing cells described by us is 2.566 points.

The nuclei of pigment-containing cells can have different shapes. The most characteristic is the concave core, i. e. a nucleus in the form of a crescent, pushed to the periphery of the cell (fig. 1, B, D, E, F). Perforated nuclei of a "torn" shape with one or two wide apertures are observed (fig. $1, \mathrm{D})$. There nuclei which we call compact have been often observed; this is a small dense nucleus with homogeneous brightly colored chromatin (fig. 1, A). Occasionally, rounded nuclei with loose chromatin or "rod-like" nuclei, similar to metamyelocyte nuclei, occur (table 1).

Nuclei with loose chromatin are characteristic for differentiating cells with intense protein synthesis. Such nuclei are found in cells with few pigment grains. However, a small number of cells with "loose" nuclei and a low nuclear-cytoplasmic ratio in all cells with a pigment content of one point indicate that the synthesis of pigments begins when the differentiation process is completed.

Further changes in the nucleus - deformation, displacement to the periphery, the appearance of holes and the disappearance of the chromatin structure - are degenerative and are associated with the accumulation of pigment. From table 1 it can be seen that as the amount of pigments increases, the fraction of compact nuclei decreases and the share of concave ones increases. A rather high percentage of concave and perforated nuclei in cells with minimum pigment content is due to the fact that during the functioning of the cell the melanin grains can be ejected from the cytoplasm into the intercellular space. We 
Table. 1. Quantity of pigments in pigment cells with a different form and structure of nucleus

\begin{tabular}{l|c|c|c|c|c}
\hline \multirow{2}{*}{ Form and structure of the nucleus } & \multicolumn{4}{|c|}{ \% of cells with a given amount of pigment } & \multirow{2}{*}{ (in points) } \\
\cline { 2 - 4 } & 1 point & 2 points & 3 points & 4 points & \\
\hline Rounded nuclei with loose chromatin & 100 & & & & 3 \\
Bean-shaped, rod-shaped & 31.3 & 31.3 & 31.3 & 6.1 & 16 \\
Compact & 16.6 & 44.4 & 25.6 & 13.4 & 223 \\
Depressed & 13.1 & 27.7 & 31.8 & 30.4 & 343 \\
Perforate & 36.6 & 41.5 & 19.5 & 2.4 & 41 \\
\hline
\end{tabular}
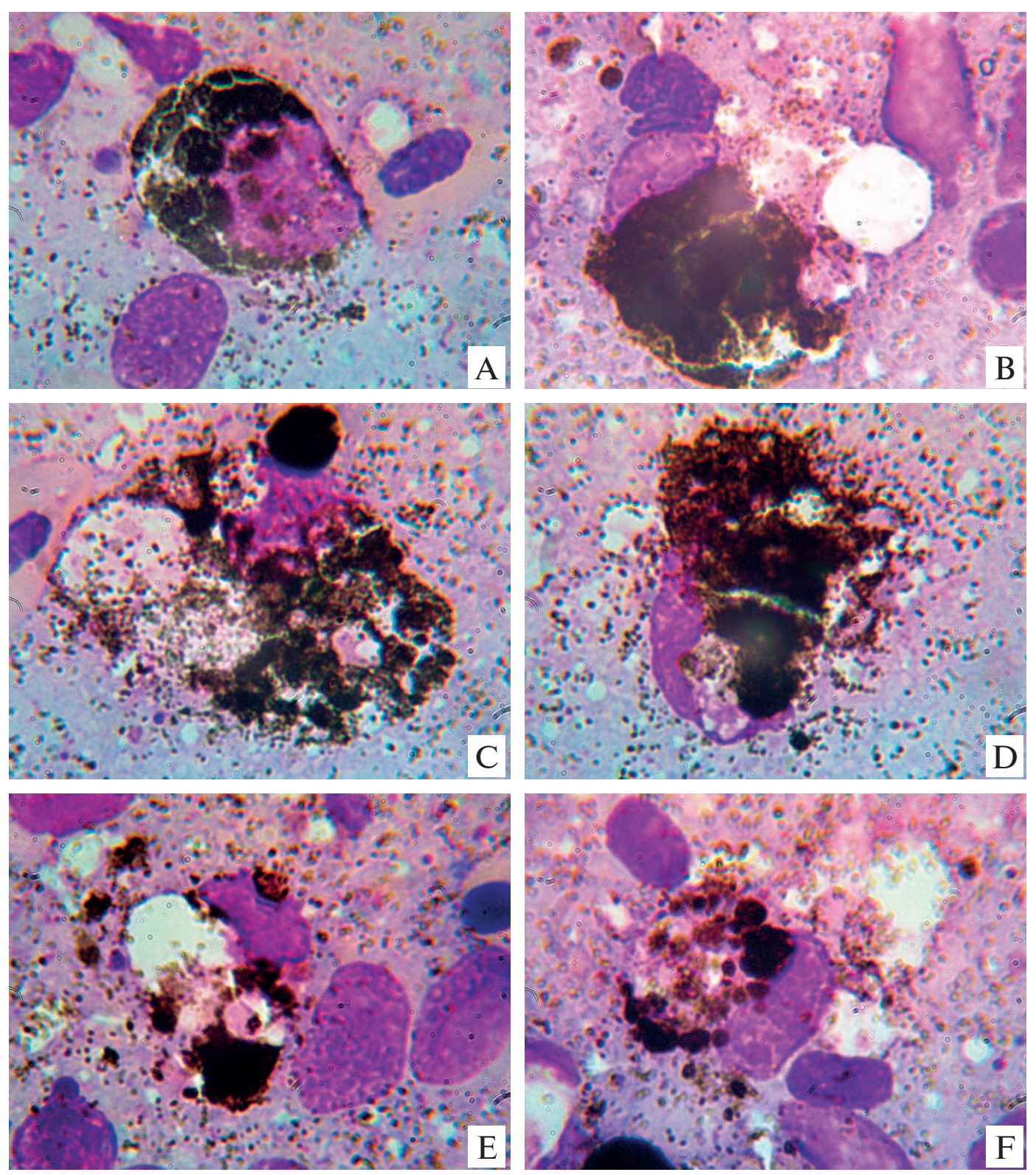

Fig. 1. Pigment cells on the smears of the frog lake liver. Coloring according to Pappenheim. x900. 

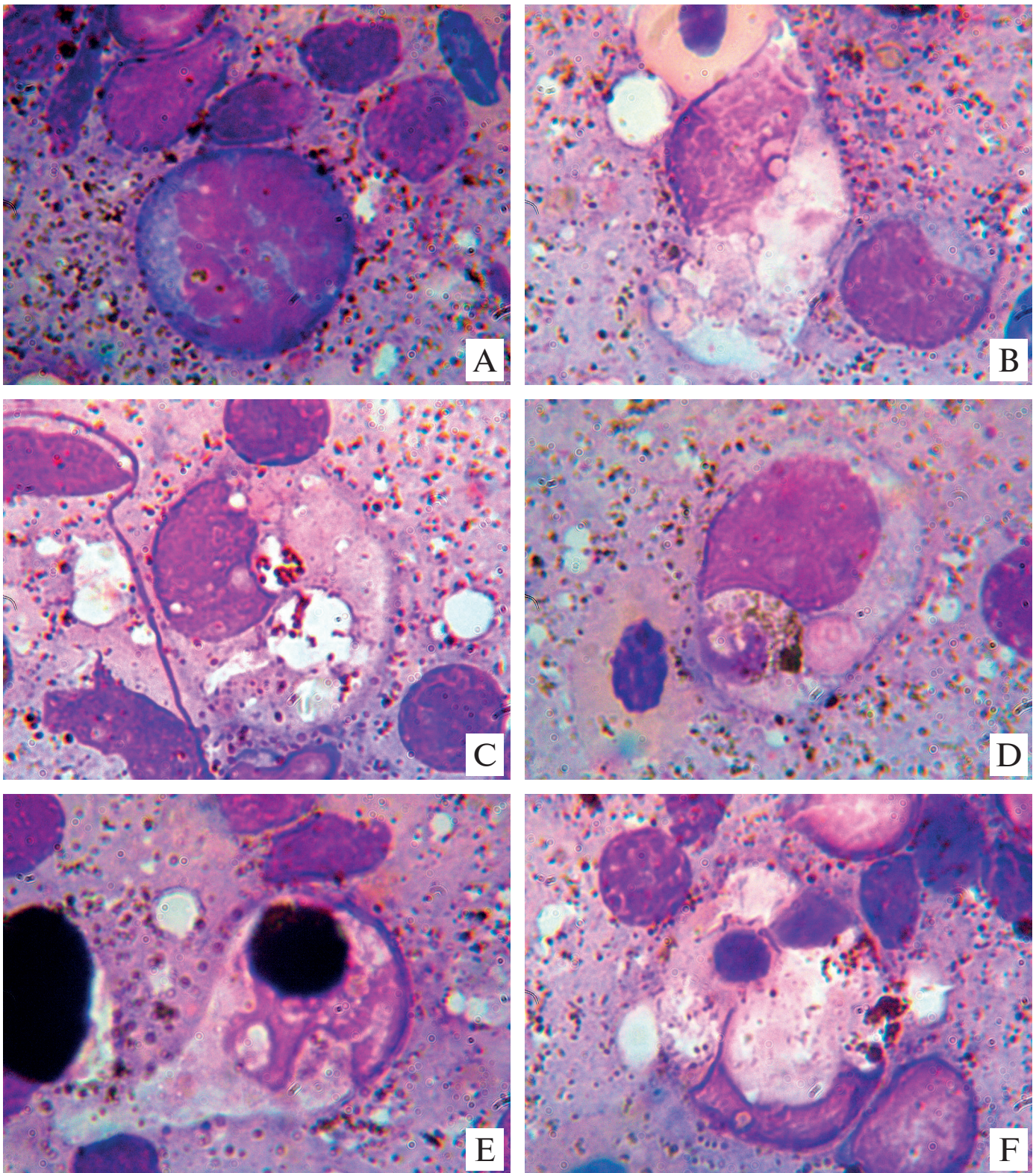

Fig. 2. Mitosis in the precursor cell of the macrophage line (A) and macrophages of varying degrees of maturity $(\mathrm{B}, \mathrm{C}, \mathrm{D}, \mathrm{E}, \mathrm{F})$ on the smears of the frog lake liver. Coloring according to Pappenheim, $\mathrm{x} 900$.

have called this process degranulation. Also, a significant number of pigment cells, having accumulated the maximum amount of pigments, perishes after the rupture of the cell membrane.

On the liver prints, cells are found - possible candidates for the role of progenitor cells of both pigment cells and macrophages. These are large cells, the cytoplasm of which is not stained with either acidic or basic dyes. Nuclei usually have irregular rounded shape, but not bean-shaped and not bay-like, which is characteristic of monocytes. Chromatin is loose, but not finely divided, but forms a fairly coarse uniform "grid" .

We also considered a population of cells that massively phagocytize sufficiently large particles. This population consists of macrophages and monocytes. The cytoplasm of monocytes is intensively stained by Pappenheim in a gray-blue color, and the nuclei have 
a complex shape: bean-shaped, bay-shaped or in the form of a rod, similar to the nucleus of a stab-shaped metamyelocyte. The macrophage cytoplasm is very poorly colored by Pappneheim, and the shape of the nucleus changes in the same way as in the pigment cells.

The phagocytic cells described by us have been divided into several groups:

1st - cells with rod-shaped, bean-shaped, bay-like nuclei (mainly monocytes)

2nd - cells with rounded nuclei with loose chromatin;

3rd - cells with compact (undeformed) nuclei with tightly condensed chromatin;

4 th - cells with depressed and perforated (deformed) nuclei.

For each of these groups, according to the results of an individual description of 1084 cells, the quantity was separately calculated:

1 - cells with a homogeneous cytoplasm;

2 - cells with vacuoles in the cytoplasm, but without traces of phagocytic particles;

3 - cells containing inside the vacuoles of inclusion of non-pigmented nature;

4 - cells in which a phagocytized pigment is found, and

5 - cells in which both pigmental and non-pigmental inclusions are found.

The presence of macrophages containing both pigment and nepigmentary inclusions in phagolysosomes is important, since it proves that the cells phagocytizing the pigment are not a particular, specific subpopulation of macrophages.

The counts are shown in table 2. Monocytes constitute about $10 \%$ of the liver phagocytes. They participate in phagocytosis less actively than macrophages. The vast majority of liver phagocytes are tissue macrophages. Among them, young forms can be distinguished - with a round or irregularly shaped oval core and loose chromatin (fig. 2, B). The presence of inclusions in $28 \%$ of the cells shows that it is also functionally mature macrophages. Subpopulation of cells with compact nuclei, consists of more mature, actively phagocytic cells (fig. 2, C, D). Finally, macrophages with concave and perforated nuclei are the terminal stage of a specific functioning with a large number of undigested inclusions (fig. 2, E, F). The accumulation of phagolisomes ultimately leads to vacuolization of the cytoplasm and to autolysis.

The origin of liver macrophages is not entirely clear. It is believed that they differentiate from monocytes of peripheral blood. But according to Bouwens (1988), liver macrophages are capable of DNA synthesis and at least $75 \%$ of Kupffer cells are produced directly in the liver, so Bouwens considers them to be basically a self-sustaining population. Our data agree with this point of view, since we observed mitoses in large cells comparable in size with the precursors of macrophages (fig. 2, A).

In the literature, as we have already noted, the data on the nature of pigment-containing cells in the amphibian liver are contradictory. Therefore, we paid special attention to the involvement or non-participation of pigment-containing cells in phagocytosis.

Table 2. Quantitative characteristic of incluson in monocytes and macrophages with a different form and nuclear structure, $\%$

\begin{tabular}{l|c|c|c|c|c|c}
\hline $\begin{array}{c}\text { Nature of the } \\
\text { inclusions }\end{array}$ & $\begin{array}{c}\text { Without } \\
\text { vacuoles }\end{array}$ & $\begin{array}{c}\text { With vacu- } \\
\text { oles, but } \\
\text { without } \\
\text { inclusions }\end{array}$ & $\begin{array}{c}\text { Inclusion } \\
\text { of non- } \\
\text { pigmented } \\
\text { nature }\end{array}$ & $\begin{array}{c}\text { Phagocytized } \\
\text { pigment }\end{array}$ & $\begin{array}{c}\text { Inclusion of } \\
\text { nonpigmental } \\
\text { nature + pig- } \\
\text { ment counted } \\
\text { cells }\end{array}$ & $\begin{array}{c}\text { Counted } \\
\text { cells }\end{array}$ \\
$\begin{array}{l}\text { The shape of the } \\
\text { nucleus }\end{array}$ & 53.6 & 17.9 & 19.6 & 7.1 & 1.8 & 112 \\
$\begin{array}{l}\text { Bean-shaped, rod- } \\
\text { shapedbay-like }\end{array}$ & 28.4 & 28.1 & 26.1 & 12.7 & 4.7 & 299 \\
$\begin{array}{l}\text { Rounded nuclei with } \\
\text { loose chromatin }\end{array}$ & 14.0 & 26.6 & 24.1 & 25.1 & 10.1 & 207 \\
$\begin{array}{l}\text { Compact } \\
\text { Depressed, perforated }\end{array}$ & 2.4 & 20.8 & 31.8 & 34.8 & 10.3 & 466 \\
\hline
\end{tabular}


Table 3. Area of pigmental cells, macrophages and monocytes on liver smears of the lake frog

\begin{tabular}{l|c|c|c}
\hline \multirow{2}{*}{ Type of cells } & \multicolumn{3}{c}{ Average area of cells (in conventional units) } \\
\cline { 2 - 4 } & young & old & mean for the whole population \\
\hline Pigment cells & $5.8+0.33$ & $5.6+0.12$ & $5.7+0.09$ \\
Macrophages & $4.4+0.09$ & $5.1+0.10$ & $4.8+0.05$ \\
$\begin{array}{l}\text { The reliability of the differences between } \\
\text { the Pigment cells and macrophages }\end{array}$ & $\mathrm{p}<0.01$ & $\mathrm{p}=0.01$ & $\mathrm{p}<0.01$ \\
Monocytes & & & $4.1+0.12$ \\
\hline
\end{tabular}

We examined and described 639 pigment cells and more than 1000 macrophages. In $56 \%$ of macrophages, phagosomes and phagolysosomes with inclusions are found, indicating phagocytic activity, namely: basophilic and azurophilic bodies, collapsing nuclei or whole cells (mainly erythrocytes), cell fragments and others (table 2, fig. 2, C, D, E, F). In cells, the cytoplasm of which is more or less evenly filled with pigment granules (pigment cells), the vacuoles are either optically empty (fig. 1, C, D, E), or they are filled with pigment in the form of continuous arrays (fig. 1, F).

Inclusions that could indicate the involvement of these cells in phagocytosis are completely absent. Moreover, the cytoplasm, filled with melanin granules or vacuoles with hemosiderin, is unlikely to form pseudopodia necessary for phagocytosis. Given the significant number of cells described by us, we can confidently conclude that cells accumulating pigment in the cytoplasm are not involved in phagocytosis and, therefore, are not melanomacrophages.

Our data also exclude the possibility that the cells accumulating the pigment in the cytoplasm are terminal stages of macrophage differentiation, according to Sichel (1988), for example. Subpopulation of cells with a minimum pigment content, according to our data, shows no signs of phagocytic activity. On the other hand, in cells representing terminal stages of differentiation of macrophages (deformed nuclei, a large number of inclusions in the cytoplasm), there are no signs of accumulation of pigments.

Using the ocular mesh, the average sizes of pigment cells and macrophages were also determined at different stages of differentiation (table 3). Young pigment cells with an undeformed nucleus and a quantity of pigments of 1-2 points were considered young. Young macrophages are also with a loose or compact nucleus and without distinct phagocytic inclusions in the cytoplasm. The cells of both lines with depressed or perforated nuclei were considered old. It was shown that the pigment and phagocytic cells significantly differ in size. This also indicates the presence of 2 cell lines. Monocytes also differ from liver macrophages in smaller sizes $(\mathrm{p}=0.01)$, the shape of the nucleus and the response of the cytoplasm, which is dyed according to Pappenheim in a gray-blue color, while the cytoplasm of macrophages and pigment cells is practically not stained.

\section{Discussion}

The data obtained by us allow us to state that there are no cells in the liver of the lake frog that are identical to the melanomacrophages described in fish. The pigment is found in two cell populations, of which the first is actually pigment cells that are not capable of phagocytosis. The second population is ordinary macrophages, the capturing pigment, which is produced and accumulated in pigment cells. A significant morphological similarity between liver pigment cells and macrophages can be a consequence of the fact that the pigment cells are a separate cell line of monocyte-macrophage origin. Thus, we do not reject the point of view of Sichel (1988) regarding the presence of "pigment cells of histiocytic origin" in the liver, but we maintain that this group of cells under normal conditions does not participate in the phagocytosis of large particles. Along with these 
cells, in the liver of the lake frog there are common tissue macrophages that interact with pigment cells, forming part of melano-macrophagic clusters (Akulenko, 1998).

In other groups of amphibians, the situation may be different. For example, in the liver of tailed amphibians pigment granules are found in outgrowth cells resembling fibroblasts (Haar, Hightower, 1976; Barni et al., 1999.) Of course, cells of this form are also incapable of phagocytizing large particles and are not melanomacrophages. Pigmentary liver cells are a kind of "metabolic histiocytes" that Diaz-Flores wrote about (1982). The assumption of distinguishing two different lines with different functions from one cell line does not contain anything incredible. This is apparently the usual way of evolution of the cellular elements of blood (Diaz-Flores, 1982). Morphological similarity, the presence of a phagocytized pigment in macrophages and the peculiarities of topographical localization led some researchers to mix two different lines of cell differentiation. In the study of histological sections, it is difficult to distinguish between two types of cells, if both contain a pigment and are in close contact in situ. According to our data, pigment cells and macrophages constantly interact in the composition of melano-macrophagic clusters and this is responsible for their close topographic proximity in the liver of the tailless amphibians (Akulenko, 1998). In this case, electron microscope research also does not provide exhaustive information, because it does not allow to examine the cells as a whole. However, our method of describing cells using specific morphological features allows us not only to identify different cell lines, but also to judge the rate of renewal and functional activity of pigment cells and macrophages.

The study of morphological changes in amphibian liver pigment cells as they mature and age has some practical significance. In particular, evidence was obtained that the liver pigment inclusions of the lake frog are used in liver repair processes after necrosis (Akulenko, 2013). The presence of specific repair mechanisms allows frogs to restore the liver after significant damage without replacing hepatocytes with fibrous formations that are characteristic of mammals (Akulenko, 2016). Thus, further study of amphibian-specific mechanisms of liver repair involving melanin, may be impotent for medicine.

The number of pigment inclusions of the liver and other internal organs of poikilothermic vertebrates and the rate of their renewal can potentially be used as a marker of the degree of anthropogenic pollution (Akulenko, 2016; Pérez-Iglesias et al., 2016; de Gregorio et al., 2016; Barros et al., 2017). Therefore, a method that allows estimating the rate of exchange of liver pigments, determining the percentage of young and old pigment cells, can be useful for developing biological methods for monitoring environmental contamination. In this way the method of quantitative description of morphological features makes it possible to study the dynamics of maturation and aging of pigment cells in the liver of tailless amphibians. Thus, it is possible to compare the exchange of pigments in the amphibian liver in normal and pathological conditions.

\section{References}

Agius, C. 1980. Phylogenetic development of melano-macrophage centres in fish. J. Zool. 191 (1), 11-31.

Akulenko, N. M. 1998. Topography and Structure of the Pigment Cell Aggregation in the Liver of the Frog (Rana ridibunda). Vestnik Zoologii, 32 (3), 49-53 [In Russian].

Akulenko, N. M. 2013. Pigmentnyye kletki pecheni beskhvostykh amfibiy: fiziologicheskaya rol' i vozmozhnoye primeneniye v tselyakh bioindikatsii. Pratsi Ukrainskoho herpetolohichnoho tovarystva, 4, 11-21 [In Russian].

Akulenko, N. M. 2016. Peculiar features of hematopoiesis in the liver of mature and immature representatives of green frogs (Pelophylax esculentus complex). Vestnik Zoologii, 50 (6), 547-552.

Arciuli,. M, Fiocco, D., Cicero, R., Maida, I., Zanna, P. T., Guida, G., Horsberg, T. E., Koppang, E. O., Gallone, A. 2012. Melanogenesis in visceral tissues of Salmo salar. A link between immunity and pigment production? Biochem Cell Biol., 90 (6), 769-778.

Barni, S., Bertone, V., Croce, A. C., Bottiroli, G., Bernini, F., Gerzeli, G. 1999. Increase in liver pigmentation during natural hibernation in some amphibians. J Anat., 195 (1), 19-25.

Barros, I. T., Ceccon, J. P., Glinski, A., Liebel, S., Grötzner, S. R., Randi, M. A. F., Benedito, E., Ortolani-Machado, C. F., Filipak Neto, F., de Oliveira Ribeiro, C. A. 2017. Environmental risk assessment in five rivers of Parana River basin, Southern Brazil, through biomarkers in Astyanax spp. Environ Sci Pollut Res Int., 24 (19), 16228-16240. 
Borucinska, J. D., Morka, D., Grabowski, Z., Smith, H. 2017. A follow-up study of selected biomarkers of health in cod Gadus morhua L. collected from the southern Baltic off the Polish coast. J Fish Dis., 40 (12), 18831894.

Bouwens, L. 1988. Structural and functional aspects of Kupffer cells. Revis Biol Celular., 16 (1), 69-94.

Carrola, J. S., Fontainhas-Fernandes, A., Rocha, E. 2019. Uncommon hepatic macrophagic foamy-cell nodules in Iberian barbel (Luciobarbus bocagei Steindachner, 1864) from the Vizela River (Portugal). Microsc Res Tech., 82 (7), 1127-1135.

Corsaro, C. 2000. Characterisation of Kupffer cells in some Amphibia. J Anat, 196 (2), 249-261.

Dang, M., Nowell, C., Nguyen, T., Bach, L., Sonne, C., Nørregaard, R., Stride, M., Nowak, B. 2019. Characterisation and 3D structure of melanomacrophage centers in shorthorn sculpins (Myoxocephalus scorpius). Tissue CellHYPERLINK “https://www.ncbi.nlm.nih.gov/pubmed/30947961”. 57, 34-41.

de Gregorio, L. S., Franco-Belussi, L., Gomes, F. R., de Oliveira, C. 2016. Flutamide effects on morphology of reproductive organs and liver of Neotropical Anura, Rhinella schneideri. Aquat Toxicol, 176, 181-189. doi: 10.1016/j. aquatox.2016.04.022.

De Souza Santos, L. R., Franco-Belussi, L., Zieri, R., Borges, R.E., De Oliveira, C. 2014. Effects of thermal stress on hepatic melanomacrophages of Eupemphix nattereri (Anura). Anat Rec (Hoboken), 297 (5), 864-875.

Diaz-Flores, L. 1982. Caracteristicas ultraestructurales de los componentos del sistema de fagocitos mononucleares. Peculiaridades topograficas. Sangre, 27 (4), 770-793.

Diaz-Satizabal, L., Magor, B. G. 2015. Isolation and cytochemical characterization of melanomacrophages and melanomacrophage clusters from goldfish (Carassius auratus L.). Dev Comp Immunol., 48 (1), 221-228.

Haar, J. L., Hightower, J. A. 1976. A light and electron microscopic investigation of the hepatic parehchyma of the adult newt, Notophthalmus viridscens. Anat. Rec., 185 (3), 313-324.

Hayhoe, F. G. H., Quaglino, D. 1983. Haematological cytochemistry. Med., Moscow, 1- 319 [In Russian].

Henninger, J. M., Beresford, W. A. 1990. Is it coincidence that iron and melanin coexist in hepatic and other melanomacrophages? // Histol Histopathol., 5 (4), 457-459.

Gutierre, R. C., Jared, C., Antoniazzi, M. M., Coppi, A. A., Egami, M. 2018. Melanomacrophage functions in the liver of the caecilian Siphonops annulatus. J Anat., 232HYPERLINK "https://onlinelibrary.wiley.com/ toc/14697580/2018/232/3" (3), 497-508.

Ribeiro, H. J., Procópio, M. S., Gomes, J. M., Vieira, F. O., Russo, R. C., Balzuweit, K., Chiarini-Garcia, H., Castro, A. C., Rizzo, E., Corrêa, J. D. Jr. 2011. Functional dissimilarity of melanomacrophage centres in the liver and spleen from females of the teleost fish Prochilodus argenteus. Cell Tissue Res., 346 (3), 417-425. doi: 10.1007/s00441-011-1286-3.

Passantino, L., Santamaria, N., Zupa, R., Pousis, C., Garofalo, R., Cianciotta, A., Jirillo, E., Acone, F., Corriero, A. 2014. Liver melanomacrophage centres as indicators of Atlantic bluefin tuna, Thunnus thynnus L. well-being. J Fish Dis., 37 (3), 241-250.

Pérez-Iglesias, J. M., Franco-Belussi, L., Moreno, L., Tripole, S., de Oliveira, C., Natale, G. S. 2016. Effects of glyphosate on hepatic tissue evaluating melanomacrophages and erythrocytes responses in neotropical anuran Leptodactylus latinasus. Environ Sci Pollut Res Int., 23 (10), 9852-9861.

Sichel, G. 1988. Biosynthesis and function of melanins in hepatic pigmentary system. Pigment Cell Res., 1 (4), 250-258.

Sichel, G., Scalia, M., Corsaro, C. 2002. Amphibia Kupffer cells. Microscopy Research \& Technique, 57 (6), 15, 477-490.

Steinel, N. C., Bolnick, D. I. 2017. Melanomacrophage Centers As a Histological Indicator of Immune Function in Fish and Other Poikilotherms. Front Immunol., 8, 827.

Received 16 October 2019

Accepted 25 August 2020 